\title{
Antioxidant Effect of Bilberry on Oxidative Stress Caused by Acute Exercise in Rats
}

\author{
Songul Doganay ${ }^{1 *} \quad$ Serap Yildırım $^{2} \quad$ Arzu Sahin $^{3} \quad$ Esra Laloglu $^{4} \quad$ Ozlem Saral $^{5} \quad$ Abdulkadir Yıldırım $^{4}$ \\ 1.Department of Physiology. Sakarya University. School of Medicine. Sakarya - Turkey \\ 2.Department of Physiology. Ataturk University. School of Medicine. Erzurum- Turkey \\ 3.Department of Physiology. Ordu University. School of Medicine. Ordu - Turkey \\ 4.Department of Biochemistry. Ataturk University. School of Medicine. Erzurum- Turkey \\ 5.Department of Nutrition And Dietetics. Recep Tayyip Erdogan University. School of Health. Rize - Turkey
}

This research is supported by Atatürk University Scientific Research Commission.

\section{Abstract}

This study, it was aimed to determine the antioxidant effect of bilberry extract in decreasing the oxidative stress caused by acute exhaustive exercises in rats' blood and liver tissues. 27 Spraque-Dawley type male rats were divided into four groups (control, exercise, bilberry and bilberry+exercise groups). Bilberry extract was administered using gavage once daily. Before blood and liver tissues were taken, the rats ran in a treadmill at a speed of $25 \mathrm{~m} / \mathrm{min}(1.5 \mathrm{~km} / \mathrm{h})$ at a slope of 0 for about 1 hour or until exhaustion. Compared to the control group, serum GSH levels and GPx activities did not have a significant change in the bilberry, acute exercise and bilberry + acute exercise groups; while serum MDA levels decreased significantly. When compared to the control group, liver GPx activity significantly increased in the bilberry and bilberry+acute exercise groups. Again, it was determined that liver GSH level significantly increased in bilberry+acute exercise group.The results of this study demonstrate that bilberry extract may provide antioxidant protection against a potential oxidative damage as it causes an increase in hepatic GPx activity and GSH levels in rats exposed to acute exhaustive exercise.

Keywords: Antioxidants, acute exhaustive exercise, bilberry, glutathione, glutathione peroxidase, malondialdehy

DOI: $10.7176 / \mathrm{JMPB} / 65-04$

Publication date: April $30^{\text {th }} 2020$

\section{Introduction}

While exercise has many beneficial effects on health ${ }^{1}$, there are many findings that a certain amount of oxidative damage occurs in muscle, liver, blood, and other tissues during exercise, and reactive oxygen species (ROS) and free radical production increase especially in intense exercises ${ }^{2-4}$.

The most significant biological change that occurs during exercise is the increase in the rate of oxygen consumption. ${ }^{5}$ In parallel with the increase in oxygen consumption, the production of the free radicals is also accelerated.6, 7 Excessive ROS production can seriously block the antioxidant defense, causing cellular homeostasis to change. Thus, lipids can initiate oxidative stress, which causes different cellular damages affecting proteins and nucleic acids. ${ }^{8-10}$ Antioxidant enzymes that are effective at the cellular level against ROS, which is produced during exercise, include SOD (superoxide dismutase), CAT (catalase), GPx (glutathione peroxidase) and GSH (Glutathione) ${ }^{11}$. It has been stated that acute exhaustive exercise may adversely affect the activities of these antioxidant enzymes ${ }^{12}$. The levels of oxidant and antioxidant molecules that are formed during the exercise vary according to the intensity and duration of the exercise ${ }^{2}$. Acute exercise leads to muscle tissue damage, lipid peroxidation in membranes and the formation of free radicals ${ }^{4}$. Regular and short-term submaximal exercises activate antioxidant systems more often while the damaging oxidant system becomes more active in intense and long exercises ${ }^{6,13}$.

Advances in scientific technology have allowed us to understand the relationship between diets and diseases, in addition, the protection of our health and the biological regulatory roles of the antioxidant nutrients in our bodies have been attracting more interest ${ }^{9}$. As the wrong nutritional habits and the medical problems emerge, it becomes clear that one of the most basic rules of living healthy and fighting diseases is a healthy nutrition ${ }^{14}$. In this context, the formation of free radicals and the determination of antioxidant capacity are important in terms of the application of antioxidant diets and/or the use of medicines in order to reduce the risk of catching such diseases ${ }^{15}$.

It has been shown that various nutrients and nutritional elements have positive effects on our health and that they contribute to the prevention and treatment of certain chronic diseases. ${ }^{16}$ It has recently been reported that bilberry extracts have cellular protective and antioxidant effects against oxidative damage formed through various in vitro models ${ }^{17,18}$. These characteristics show that it is a good choice for studies on nutrition ${ }^{19,20}$. Studies have also reported that the consumption of this fruit slows down physiological and functional disorders associated with age ${ }^{21}$. Studies have indicated that this plant has been used in the traditional treatment of liver 
diseases, as well as using its characteristics of controlling blood pressure, serum glucose and serum lipid levels ${ }^{22}$, and also urinary antiseptic ${ }^{23}$, anti-inflammatory, antidiabetic and anticancer effects together with its antioxidant properties $^{24}$.

In this study, we aimed to investigate whether there's a protective effect of bilberry, which has strong antioxidant properties against oxidative stress caused by acute exhaustive exercise, on the liver and serum tissues of rats. For this purpose, MDA and GSH levels and GPx activities were measured in liver homogenate and serum tissue specimens and compared with the control group.

\section{Material and Methods}

\subsection{Determination of Experimental Animals and Exercise Protocol}

In this study, 27 two months old, male, Spraque-Dawley type rats with average weights ranging from $280-300 \mathrm{~g}$ were used. During the experiment, the rats, which were kept in wire cages in the $12 / 12$ hour light/dark cycle of light, at a temperature of $22^{\circ} \mathrm{C}$, and in 50-60\% humidity, were fed with standard pellet feed and tap water.

The exercising group's running exercises were carried out on a four-way treadmill (May Time 0804 Animal Treadmill) with an electric motor drive. Before starting the exercise protocol, the rats were allowed to run on the treadmill for 10 minutes a day for 5 days at a rate of $10 \mathrm{~m} / \mathrm{min}(0.9 \mathrm{~km} / \mathrm{h})$ at a slope of 0 for being familiarised. During acute exhaustive exercise, the rats ran on the treadmill at a speed of $25 \mathrm{~m} / \mathrm{min}(1.5 \mathrm{~km} / \mathrm{h})$ at a slope of 0 for about 1 hour or until being exhausted ${ }^{25}$.

\subsection{Preparation of Bilberry Extract}

The Bilberry fruit collected from Artvin region was dried at $40^{\circ} \mathrm{C}$ before the analysis and the dried fruit was grounded. For the analyses, about $400 \mathrm{~g}$ of grounded dry sample was taken and enough water was added to exceed the sample. The prepared sample was stirred for one day, and it was filtered and diluted with water to a concentration of $100 \mathrm{mg} / \mathrm{kg}$. Antioxidant activities were then monitored.

\subsection{Creation of Experiment Groups}

Control Group $(\boldsymbol{C}, \boldsymbol{n}=\mathbf{6})$ : No extra treatment was applied to rats, which were kept in standard conditions.

Bilberry Group $(\boldsymbol{B}, \boldsymbol{n}=7)$ : Bilberry extract was administered to the rats housed under standard conditions at a dose of $1 \times 100 \mathrm{mg} / \mathrm{kg} /$ day, using 2 cc gavage daily for 30 days.

Exercise Group $(\boldsymbol{E}, \boldsymbol{n}=\mathbf{6})$ : The rats in this group were familiarised with the treadmill for 10 minutes at a speed of $10 \mathrm{~m} / \mathrm{min}(0.9 \mathrm{~km} / \mathrm{h})$ at the inclination of 0 for 5 days before starting the exercise protocol. Then, before the tissues were taken, they ran in the treadmill for about 1 hour or until exhaustion at a speed of $25 \mathrm{~m} / \mathrm{min}(1.5$ $\mathrm{km} / \mathrm{h}$ ) at an inclination of 0 within the acute exhaustive exercise program.

Bilberry + Exercise Group $(\boldsymbol{B}+\boldsymbol{E}, \boldsymbol{n}=8)$ : The rats housed under standard conditions were given bilberry extracts at a dose of $1 \times 100 \mathrm{mg} / \mathrm{kg} /$ day, using $2 \mathrm{cc}$ gavage daily for 30 days. They were then acclimated to the treadmill for 10 minutes at a speed of $10 \mathrm{~m} / \mathrm{min}(0.9 \mathrm{~km} / \mathrm{h})$ at 0 inclination for 5 days prior to beginning the exercise protocol. On the last day, the 31 st day of the experiment, the acute exhaustive exercise was carried out making the rats run on the treadmill for about 1 hour at a speed of $25 \mathrm{~m} / \mathrm{min}(1.5 \mathrm{~km} / \mathrm{h})$ at 0 inclination or until exhaustion.

Bilberry extracts were not given to the rats on the day of the collection of the tissues and blood samples were taken intracardially under general anesthesia (when there was no response to the painful stimulus). The liver tissues were taken after the hemorrhagic shock.

\subsection{Preparation of the Samples}

Blood specimens were placed in tubes without anticoagulants, were kept at room temperature until completely coagulated, and then they were centrifuged at $4{ }^{\circ} \mathrm{C}$ for $5 \mathrm{~min}$ at $3500 \mathrm{x} \mathrm{g}$, and afterward, serum fractions were separated and they were stored at $-80^{\circ} \mathrm{C}$ until biochemical measurements.

\subsubsection{Preparation of liver Homogenates}

The extracted liver tissue was thoroughly washed with ice-cold isotonic $\mathrm{NaCl}$ solution to remove the bloody parts and the wetness was removed with the drying paper. The tissue was stored in a deep freezer at $-80^{\circ} \mathrm{C}$ until the analysis. On the day of the measurements, approximately $300 \mathrm{mg}$ of wet tissue was homogenized in $3 \mathrm{ml}$ of phosphate buffer (50 mM pH 7) for GPx and GSH measurements, and in $1.15 \% \mathrm{KCl}$ solution for MDA measurement (OMNI International, USA). Tissue homogenates were centrifuged at 10,000 x $\mathrm{g}$ for 15 minutes at $4^{\circ} \mathrm{C}$, and their supernatants were taken and these supernatants were used for GPx and GSH measurements. Additionally, the MDA measurements were performed using tissue homogenates.

\subsubsection{Malondialdehyde (MDA) Measurement}

The principle of the experiment is based on the absorbance of the pink colored complex, which is formed by thiobarbituric acid and MDA, and which is spectrophotometrically measured at a wavelength of $532 \mathrm{~nm}$, after the incubation at $95^{\circ} \mathrm{C}$. 26 Sodium dodecyl sulphate (SDS) solution (8.1\%), 20\% acetic acid solution (pH 3.5, 
adjusted with $\mathrm{NaOH}), 0.9 \%$ thiobarbituric acid (TBA) solution, n-Butanol/Pyridine (15/1, v/v) solutions were prepared as the measurement reagents. As a standard, 1.1.3.3 tetraethoxypropane (Sigma) was used, and a stock standard solution at $0-200 \mu \mathrm{mol} / \mathrm{L}$ concentration was prepared. Serial dilutions were made from the stock standard to obtain solutions at a concentration range of $0-200 \mu \mathrm{mol} / \mathrm{L}$, and it was used as the measurement standard.

\subsubsection{Glutathione Peroxidase (GPx) Activity Measurement}

In the determination of GPx activity, a commercially produced measurement kit (Glutathione Peroxidase Assay Kit, Cat No: 703102, Cayman Chemical, Ann Arbor, MI, USA) was used. GPx activity has been carried out in accordance with the manufacturer's recommendations on the measuring method. Enzyme activity was calculated using the molar absorbance coefficient of NADPH $\left(0.00373 \mu \mathrm{M}^{-1} . \mathrm{cm}^{-1}\right.$ for $0.6 \mathrm{~cm}$ microplate light path $)$. GPx activity was expressed as $\mathrm{U} / \mathrm{mL}$ (for serum) or $\mathrm{U} / \mathrm{g}$ protein (for tissue).

\subsubsection{Glutathione (GSH) Measurement}

The GSH level measurement was performed in accordance with the recommendations of the manufacturer company using a commercial kit (Glutathione Assay Kit, Cat No: 703002, Cayman Chemical, Ann Arbor, MI, USA). GSH level was expressed as mol/L (for serum) or mol/g protein (for tissue).

\subsubsection{Protein Measurement}

Protein measurement in tissue supernatant samples was performed according to the Bradford method. ${ }^{26}$ Protein values were used to calculate the tissue concentration or the specific activity for GSH and GPx.

\subsection{Statistical Analysis}

Statistical analysis of the data was performed using the PASW Statistics 18.0 (SPSS Inc., Chicago, IL) program. The variables' suitability to the normal distribution was assessed by the Kolmogorov-Smirnov test. Intergroup comparisons were analyzed by One-Way ANOVA LSD Post Hoc test. The differences, where $\mathrm{P}<0.05$, were considered as statistically significant.

\section{Resuls}

\subsection{Group Weights}

When compared with the $\mathrm{C}$ group, there were no significant differences in the body weights among the groups. Group weights are shown in Table 1.

Table 1 . Body weights of rats in the study groups

\begin{tabular}{|l|c|c|c|c|c|}
\hline \multirow{2}{*}{ Groups } & \multicolumn{4}{|l|}{ Average Rat Body Weights (g) } & \multicolumn{2}{l|}{$\begin{array}{l}\text { Final Weighing } \\
\left(\mathbf{3 0}^{\text {th }} \text { day }\right)\end{array}$} & $\begin{array}{l}\text { First Weighing } \\
\left(1^{\text {st }} \text { day }\right)\end{array}$ & $\mathbf{3 3 9}$ & $\mathbf{3 0}$ & $+\mathbf{3 0}$ \\
\hline Control & $\mathbf{n}$ & $\mathbf{3 0 9}$ & $\mathbf{3 1 8}$ & $+\mathbf{1 5}$ & $+\mathbf{5}$ \\
\hline Bilberry & $\mathbf{6}$ & $\mathbf{3 0 3}$ & $\mathbf{3 3 3}$ & $+\mathbf{2 6}$ & $+\mathbf{8}$ \\
\hline Exercise & $\mathbf{6}$ & $\mathbf{3 0 5}$ & $\mathbf{3 2 6}$ & $+\mathbf{2 1}$ & +7 \\
\hline Bilberry+ Exercise & $\mathbf{8}$ & & &
\end{tabular}

\subsection{Biochemical Findings}

\subsubsection{Blood tissue oxidant/antioxidant parameters}

Serum GSH, GPx and MDA values measured on the study groups are presented in Fig. 1, while liver homogenate GSH, GPx and MDA values are shown in Fig. 2. Serum MDA, GSH levels and GPx activities of B, $\mathrm{E}$ and $\mathrm{B}+\mathrm{E}$ groups were compared with the $\mathrm{C}$ group, there was no significant difference in GSH levels and GPx activities, while serum MDA levels decreased in a significant rate. 


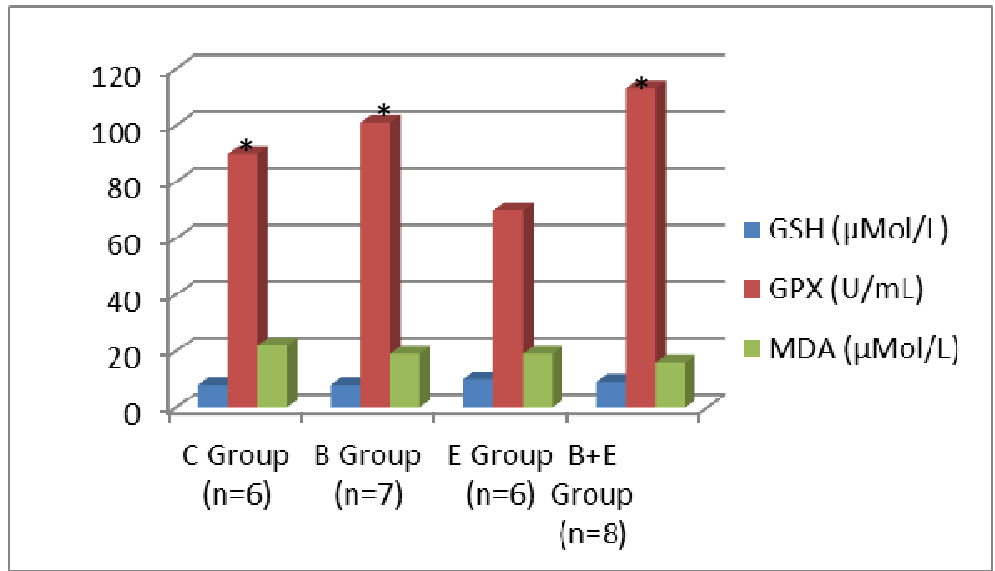

C: Control; B: Bilberry; E: Exercise; B+E: Bilberry+Exercise: GSH: Glutathione; GPx: Glutathione peroxidase; MDA: Malondialdehyde

Figure 1: The measured serum GSH, GPx and MDA values, GSH levels and GPx activities ( $\mathrm{p}>0.05$ for all of them), *MDA levels of group $B$, group $E$, and group $B+E(p=0.011, p=0.013$ and $p=0.0001$, respectively)

\subsubsection{Liver tissue oxidant/antioxidant parameters}

The GPx activity in the liver was significantly increased in the B group and the B+E group when compared to the $\mathrm{C}$ group, and the liver GSH level was significantly increased in the B+E group, whereas the MDA concentration did not change significantly (Figure 2).

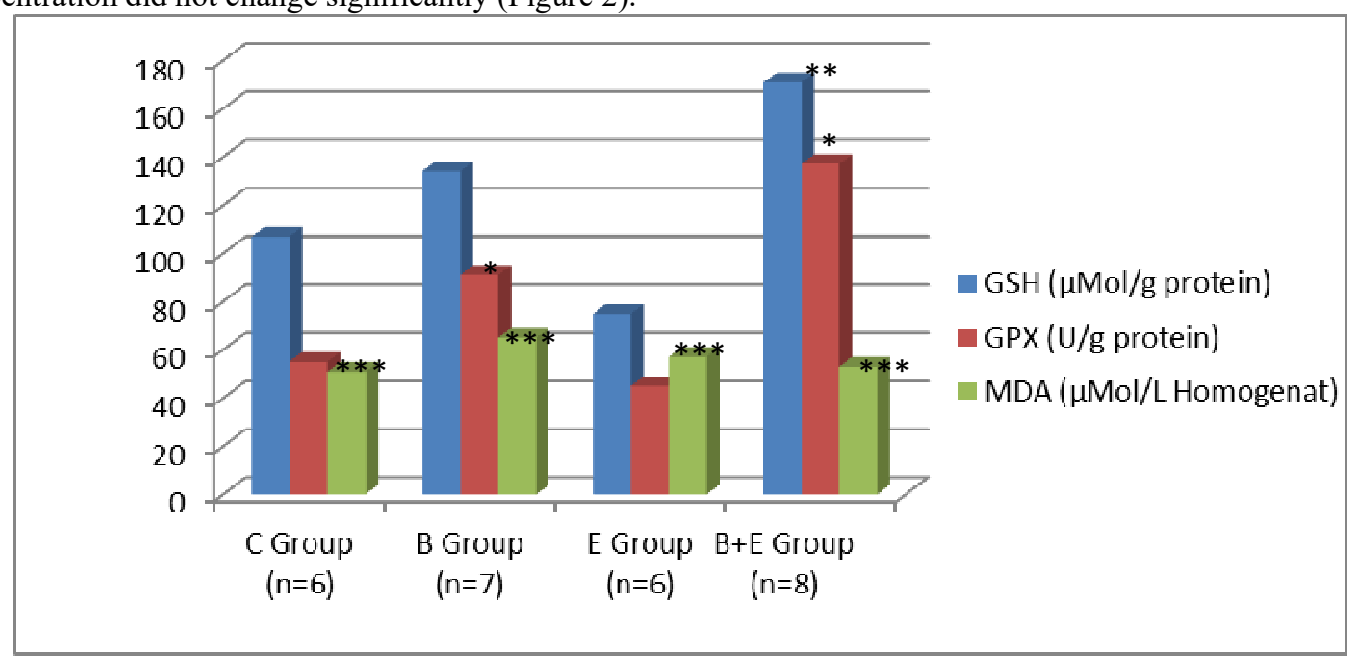

C: Control; B: Bilberry; E: Exercise; B+E: Bilberry+Exercise: GSH: Glutathione; GPx: Glutathione peroxidase; MDA: Malondialdehyde

Figure 2: GSH, GPx and MDA values of the liver tissue. * GPx activities of Group B and Group B+E ( $\mathrm{p}=0.030$ and $\mathrm{p}=0.0001$, respectively). ${ }^{* *} \mathrm{GSH}$ of Group $\mathrm{B}+\mathrm{E}(\mathrm{p}=0.005),{ }^{* * *}$ MDA levels $(\mathrm{p}=0.711)$.

\section{Discussion}

It is known that exercise is a stress source that enhances the oxidative stress by increasing the production of free oxygen radicals, on the other hand it affects the activity of antioxidant enzymes and develops resistance to oxidative stresses ${ }^{27}$. Short exercise, which can be evaluated as a system that activates the antioxidant system instead of oxidant system, or sweeps away the oxidant products that have formed, can act as an antioxidant mechanism. It has been shown in many studies that, the duration of exercise and its intensity have effects on this situation $^{28-31}$. It is stated that acute exhaustive exercise enhances the formation of the free radicals and this increase can be proved by the increase of lipid peroxidation, glutathione oxidation and oxidative protein damage $^{32}$.

In our study, serum acute MDA levels in groups $\mathrm{B}, \mathrm{E}$ and $\mathrm{B}+\mathrm{E}$ decreased significantly after acute exhaustive exercise, when compared to the $\mathrm{C}$ group. We suggest that bilberry extract, which has low MDA levels and a high antioxidant power, accelerates the oxidative stress by increasing antioxidant enzyme activities. When the serum antioxidant parameters were examined in our study, it was seen that there was no significant difference in serum GSH levels and GPx activities in groups B, E and B + E when compared to the C group. The 
GPx activity was found to be higher in the B and B+E groups than in the other groups, however, this increase was not statistically significant. When studies in the literature are examined, the fact that different results have been observed in GSH and GPx activities only after acute exercise supports our results.

Tavera et $\mathrm{al}^{33}$. reported that anthocyanins were observed in the plasma of rats within $30 \mathrm{~min}$, and that plasma antioxidant levels increased significantly after 3-6 hours of feeding compared to the control group, in the group fed with bilberry extract. Rokitzki et $\mathrm{al}^{34}$. observed that there was no significant change in GPx levels in intensely-trained athletes and skiers, while there was an increase in MDA after intense exercise, by antioxidant supplementation 4.5 weeks before long-distance runs in intensely-trained runners and skiers. Sahlin et $\mathrm{al}^{35}$. found that MDA and total GSH increased in acute exercise. On the contrary, Thirumalai et $\mathrm{al}^{36}$. reported a significant decrease in GPx levels in rats subjected to a 5-day intensive and comprehensive swimming training program. Again, Aguilo et $\mathrm{al}^{37}$. reported that there was a significant decrease in serum GPx after acute cycling. The results of these studies have emphasized that acute exhaustive exercises reduce antioxidant capacity and that supplementation of antioxidant agents prior to acute exercise may be beneficial in increasing antioxidant capacity.

When the literature is examined, a large number of studies have been found indicating that short-term or acute intensive exercises increase the oxidative stress.

Alessio et $\mathrm{al}^{38}$. reported that MDA did not change in exhaustive aerobic exercise, Duffaux et $\mathrm{al}^{39}$. reported that MDA did not show a significant increase after intensive running test in physical education students, and Leaf et $\mathrm{al}^{40}$. stated that MDA did not change in before, after and during maximal exercise. Grisham ${ }^{41}$ did not find a significant difference in MDA during acute exercise. Similarly, Dernbach et $\mathrm{al}^{42}$. reported that there was no change in plasma MDA levels before and after the 4-weeks of intensive rowing training and during recreation in the athletes. Selamoglu ${ }^{43}$ has found a statistically significant decrease in the MDA in long-distance runners. As in our study, there are many studies that have found a decrease in MDA levels and have supported our results. Celik et $\mathrm{al}^{44}$. reported that the football players had a decrease in MDA levels after acute exercise. Aksu et $\mathrm{al}^{45}$. reported that acute exercise did not produce oxidative stress in rat brain (prefrontal cortex, striatum and hippocampus) as the result of their study. They explained these findings in the way that the effects of free radicals on different organs may also be different. It has been reported that at least some of these conflicting results regarding MDA levels may be due to changes in the plasma volume that the exercises cause ${ }^{46}$.

It has been supported by the studies that, although there are numerous known benefits of the moderate level and regular exercises, the acute exhaustive exercise causes oxidative stress and accordingly oxidative damage in the tissues of the many vital organs such as blood, liver, kidney, and brain ${ }^{47}$. The utilization of antioxidant agents may provide certain protection against the damaging effects of radicals and may also prevent the side effects that may occur by partially inhibiting free radical formation caused by exercise. For example, the use of antioxidants such as $\mathrm{C}$ and $\mathrm{E}$ vitamins has been reported by the studies to be partially protecting against exercise-mediated oxidative damage in both people and rats $^{48}$.

Davies et al. ${ }^{49}$ reported that free radical concentration, MDA and mitochondrial damage in liver and muscle homogenates of the rats fed with antioxidant diet and having acute exhaustive exercise were only higher than the rats fed with vitamin $\mathrm{E}$, when compared with exercise groups receiving exhaustive exercise but not antioxidant supplementation, while there was a $100 \%$ increase in their levels of MDA. Knez et al. ${ }^{50}$ reported a significant increase in MDA levels in both groups in their study on semi-and full-distance triathlon runners, while there was a decrease in GPx levels.

It has been reported that chronic liver disease begins with oxidative stress and that intense stress causes significant DNA damage, structural abnormalities in the liver and hepatocellular carcinoma ${ }^{51,52}$. It has been observed that anthocyanins and other phenolic compounds found in berry fruits and plants exhibit antioxidant effects both in damage and inflammation, which occur in the liver via alcohol or other toxins ${ }^{53,54}$. In general, the total antioxidant capacity of liver tissue is regulated by GSH, C, E vitamins and possibly by other homeostatic mechanisms including various endogenous components. GSH is a very important antioxidant, which is found in tissues. For this reason, increasing the GSH level may be beneficial in the extinction of the reactive oxygen species in the cell ${ }^{42}$. Certain studies have shown that deficiency of glutathione in the pathophysiology of many diseases can be prevented or reversed by providing GSH or GSH precursors ${ }^{55}$. Luo et al. ${ }^{56}$ reported that bilberry extract takes part in preventing liver damage and oxidative stress development.

In our study, when the liver homogenate GSH, GPx activity results were compared to the $\mathrm{C}$ group. It was observed that there was a significant increase in liver GPx activity of B and B+E groups, there was a significant increase in the liver GSH levels of $\mathrm{B}+\mathrm{E}$ group compared to the $\mathrm{Cl}$ group, while there was no significant change in MDA concentrations. The increase in liver homogenates of GSH and GPx activity of the Bilberry-consuming groups suggests that it may have originated from bilberry, which is a powerful antioxidant. The studies in the literature are consistent with the values that we have found on the liver homogenates. Talavera et al..$^{57}$ found that the amount of liver anthocyanin in rats fed with an anthocyanin-rich diet for 15 days was considerably high. Kalt et al. ${ }^{58}$ reported that there were high amounts of anthocyanin in the liver, eye, cortex and cerebellum of pigs fed 
with bilberry for 4 weeks; and Tang et al. ${ }^{59}$ reported that bilberry extract not only reduces liver damage but also decreases the oxidative stress in rats.

Bao et al.$^{60}$ reported that plasma MDA levels were lowest, and the liver GSH and vitamin C levels were the highest in rats fed with $200 \mathrm{mg} / \mathrm{kg} /$ day, in their study that they administered the bilberry extract and vitamin $\mathrm{C}$ at different doses orally, before their five-day fasting, to the rats, to whom they applied limited hunger stress for 18 hours. Sakakibara et al. ${ }^{61}$, and Lchiyanagi et al. ${ }^{62}$ reported that the accumulation of anthocyanin is most abundant in the liver, in their studies examining the distribution and absorption of anthocyanins present in bilberry extracts by various organs of mice

\section{Conclusions}

As the result, numerous studies have shown that the antioxidant defense system, which is suppressed during the situations that the exercise stress is triggered, can be compensated by the application of antioxidant agents from the outside, and that oxidative stress decreases as a natural end-result of this application. Supplementing antioxidants to those who exercise may be beneficial to reduce oxidative stress and increase antioxidant capacity. Using antioxidant supplements can also increase the performance of those who exercise. For this reason, we believe that further and advanced studies are required.

\section{Acknowledgment}

This article is prepared from PhD thesis.

\section{References}

1. Ji LL. (1999). Antioxidants and oxidative stress in exercise. Proceedings of the Society for Experimental Biology and Medicine. 222, 283-292

2. Ji LL, Leeuwenburgh C, Leichtweis S, Gore M, Fiebig, R, Hollander J, Bejma J. (2006), Oxidative stress and aging: role of exercise and its influences on antioxidant systems. Annals of the New York Academy of Science, 854, 102-117

3. König D, Wagner KH, Elmadfa I, Berg A. (2001). Exercise and oxidative stress: significance of antioxidants with reference to inflammatory, muscular, and systemic stress. Exercise Immunulogy, 7, 108133.

4. Kocyigit Y, Aksak MC, Atamer Y, Aktas A. (2011). The effect of vitamin C application on liver enzymes and plasma lipid levels in footballers and basketball players. Journal of Clinical and Experimental Investigation,. 2 (1), 62-68.

5. Arslan R. (1997). Investigation of the effect of acute and programmed lower axial exercise on lipid peroxidation and antioxidant defense system of erythrocyte membrane in sedanter. Yuzuncu Yil University Health Sciences Institute PhD Thesis in Department of Physiolog, Van.

6. Palmer FM, Nieman DC, Henson DA, Mcanulty SR, Mcanulty L, Swick, NS, Utter AC, Vinci DM, Marrowet JD. (2003). Influence of vitamin C supplementation on oxidative and salivary 1ga changes following an ultramarathon. European Journal of Applied Physiology, 89, 100-107.

7. Selcuk M. (2003). The effects of programmed aerobic and anaerobic exercise on some antioxidant profiles in sedantery and sportmen doing nordic discipline. Yuzuncu Yil University, Health Sciences Institute PhD Thesis in Department of Physiology. Van.

8. Coskun T. (2005). Effects of functional foods on our health. Journal of child health and illness. 48, 69-849.

9. Duncan K, Harries S, Ardies CM. (1997). Running exercise may reduce risk for lung and liver cancer by inducing activity of antioxidant and phase II enzymes. Cancer Letters, 116: 151-158.

10. Aydın A, Sayal A, Isımer A. (2001). Free radicals and antioxidant defense system. Ankara Gülhane Military Medical Academy Printing House, 20, 48

11. Abed KE, Rebai H, Bloomer RJ, Trabelsi K, Masmoudi L, Zbidi A, Sahnoun Z, Hakim A, Tabka Z. (2011). Antioxidant status and oxidative stress at rest and in response to acute exercise in judokas and sedentary men. Journal of Strength \& Conditioning Research, 25(9), 2400-2409.

12. Sabbag C, Surucuoglu MS. (2011). Lycopene: An Essential Component In Human Health. Electronic Journal of Food Technologies, 6(3), 27-41.

13. Ozturk M, Guzelhan Y, Sayar K, Tuzun U. (2001). Investigation Of The Plasma Malondialdehyde And Gluthatione Levels In Children With Pervasive Developmental Disorder. Bulletin of Clinical Psychopharmacology, 11, 155-159.

14. Fang YZ, Yang S, Wu G. (2002). Free radicals, antioxidants and nutrition, Nutrition 18:872-879.

15. Giovanelli G, Buratti S. (2009). Comparison of polyphenolic composition and antioxidant activity of wild Italian blueberries and some cultivated varieties. Food Chemistry, 112, 903-908.

16. Ji LL, Leichtweis S. (2006). Exercise and oxidative stress: source of free radicals and their impact on 
antioxidant systems. Age (Omaha) , 2, 278-291.

17. Aragon SM, Basabe B, Juana M, Villar B, Villar AM. (1998). Antioxidant action of Vaccinium myrtillus L. Phytother. Phytotherapy Research, 12, 104-106.

18. Valentova K, Ulrichova J, Cvak L, Simanek V. (2007). Cytoprotective effect of a bilberry extract against oxidative damage of rat hepatocytes. Food Chemistry, 101, 912-917.

19. Naczk M, Grant S, Zadernowski R, Barre E. (2006). Protein precipitating capacity of phenolics of wild blueberry leaves and fruits. Food Chemistry, 96, 640-647

20. Kechinski CP, Guimaraes PV, Norena CP, Tessaro IC, Marczak LD. (2010). Degradation kinetics of anthocyanin in blueberry juice during thermal treatment. Journal of Food Science, 75(2), 173-176.

21. Jakesevic M, Aaby K, Borge GIA, Jeppsson B, Ahrne S, Molin G. (2011). Antioxidative protection of dietary bilberry, chokeberry and Lactobacillus Plantarum HEAL19 in mice subjected to intestinal oxidative stress by ischemia-reperfusion. BMC Complementary and Alternative Medicine, 27, 8-11.

22. Khalili A, Khosravi MB, Nekooeian AA. (2011). The effects of aqueous extract of Vaccinium Arctostaphylos leaves on blood pressure in renal hypertensive rats. Iranian Red Crescent Medical Journal, 13(2), 123-127.

23. Feshani AM, Kouhsari SM, Mohammadi S. (2011). Vaccinium Arctostaphylos, a common herbal medicine in Iran: molecular and biochemical study of its antidiabetic effects on alloxan-diabetic Wistar rats. Journal Ethnopharmacol, 133: 67-74.

24. Domitrovic RJH. (2011). Effects of standardized bilberry fruit extract on resolution of CCl4-induced liver fibrosis in mice. Food Chemistry Toxicology. 49(4), 848-854.

25. Ji LL, Wu E. (1990). Alteration of antioxidant enzymes with aging in rat skeletal muscle and liver. American Journal of Physiology, 258, 918-923.

26. Ohkawa H, Ohishi N, Yagi K. (1979). Assay for lipid peroxides in animal tissues by thiobarbituric acid reaction. Analytical Biochemistry, 95, 351-358.

27. Bradford M. (1976). A rapid and sensitive method for the quantitation of microgram quantities of protein utilizing the principle of protein-dye binding. Analytical Biochemistry, 72, 248-254.

28. Aguilo A, Tauler P, Pilar Guix M, Villa G, Cordova A, Tur JA, Pons A. (2003). Effect of exercise intensity and training on antioxidants and cholesterol profile in cyclists. The Journal of Nutritional Biochemistry, 14: 319-325.

29. Radak Z Sasvari M, Nyakas C, Pucsok J, Nakamoto H, Goto S. (2000). Exercise preconditioning against hydrogen peroxide-induced oxidative damage in proteins of rat myocardium. Archives of Biochemistry and Biophysics, 376, 248-251.

30. Timothy IM, Kevin EE, Hageman KS, Poole DC. (2003). Altered regional blood flow responses to submaximal exercise in older rats. Journal of Applied Physiology, 96, 81-88.

31. Banerjee AK, Mandal A, Chanda D, Chakraborti S. (2003). Oxidant, antioxidant and physical exercise. Molecular and Cellular Biochemistry, 253, 307-312.

32. Atalay M, Oksala NK, Laaksonen DE, Savita Khanna, Chitose Nakao, Jani Lappalainen, Sashwati Roy, Osmo Hanninen, Sen CK. (2004). Exercise training modulates heat shock protein response in diabetic rats. Journal of Applied Physiology, 97, 605-611.

33. Ajmani RS, Fleg JL, Demehin AA, Wright JG, O'Connor F, Heim JM. (2003). Oxidative stress and hemorheological changes induced by acute treadmill exercise. Clinical Hemorheol Microcirc, 28(1), 29-40.

34. Talavera S, Felgines C, Texier O, Besson C, Mazur A, Lamaison JL, Remesy C. (2006). Bioavailability of a bilberry anthocyanin extract and its impact on plasma antioxidant capacity in rats. Journal of the Science of Food and Agriculture, 86, 90-97.

35. Rokitzki L, Logemann E, Sagredos AN, Murphy M, Wetzel-Roth W, Scand K. (1994). Lipid peroxidation and antioxidative vitamins under extreme endurance stress. Journal Acta Physiologica, 151, 149-158.

36. Sahlin K, Ekberg K, Cizinsky S. (1991). Changes in plasma hypoxanthine and free radical markers during exercise in man. Acta Physiologica Scandinavica, 141, 275-281.

37. Thirumalai T, Viviyan Therasa S, Elumalai EK, David E. (2011). Intense and exhaustive exercise induce oxidative stress in skeletal muscle. Asian Pacific Journal of Tropical Disease, 63-66.

38. Aguilo A, Tauler P, Fuentespina E, Tur JA, Cordova A, Pons A. (2005). Antioxidant response to oxidative stress induced by exhaustive exercise. Physiology \& Behavior, 84,1-7.

39. Alessio HM Hagerman AE, Fulkerson BK, Ambrose J, Rice RE, Wiley RL. (2000). Generation of Reactive Oxygen Species after Exhaustive Aerobic and Isometric Exercise Medicine Science, Sports Exercise, 32(9), 1576-1581.

40. Duffaux B, Heine O, Kothe A, Prinz U, Rost R. (1997). Blood glutathione status following distance running. International Journal Sports Medicine. 18, 89-93.

41. Leaf DA. (1997). The effect of exercise intensity on lipid peroxidation. Medicine Science Sports 
Exercise, 29(8), 1106-1109.

42. Grisham MB. (992). Reactive metabolites of oxygen and nitrogen in biology and medicine. RG Landes Company, 1, 5-28.

43. Dernbach AR, Sherman WM, Simonsen JC, Flowers KM, Lamb DR. (1993). No evidence of oxidant stress during high intensity rowing training. Journal of Applied Physiology, 74(5), 2140-2145.

44. Selamoglu S. (2000). The effect of aerobic and anaerobic training on the athletes' defense system. Institute of Health Sciences (PhD), Izmir: Dokuz Eylül University.

45. Celik A, Varol R, Onat T, Dağdelen Y, Tugay F. (2007). The Effects Of Acute Exercıse On The Parameters Of Antioxidant System In Football Players. Journal of Physical Education and Sports Sciences, 4, 167-172.

46. Aksu I, Topcu A, Camsari UM, Acikgoz O. (2009). Effect of acute and chronic exercise on oxidantantioxidant equilibrium in rat hippocampus, prefrontal cortex and striatum. Neuroscience Letters, 452, 281 285.

47. Tas M. (2006). The effect of sprint exercises on serum superoxide dismutase, catalase and malondialdehyde levels in soccer players. Health Sciences Institute, Physical Education and Sports Department (MA), Erzurum: Atatürk University.

48. Zergeroğlu AM, Ersöz G, Yavuzer S. (1997). Antioxidant Defense in The Endurance Training. Hacettepe Journal of Sport Sciences, 8(4), 25-31.

49. Vina J, Mina JB, Gomez-Cabrera MC, Lloret A, Marquez R, Pallard FV, Sastre J. (2000). Free radicals in exhaustive physical exercise. IUBMB Life, 50(4-5), 271-277

50. Davies KJA, Quintanilha AT, Brooks GA, Packer LC. (1982). Free radicals and tissue damage produced by exercise. Biochemical and Biophysical Research Communications, 107, 1198-1205.

51. Knez WL, Jenkıns DG, Coombes JS. (2007). Oxidative stress in half and full Ironman triathletes. Medicine \& Science in Sports \& Exercise, 39, 283-288.

52. Adams DH, Ju C, Ramaiah SK, Uetrecht J, Hartmut J. (2010). Mechanisms of immune-mediated liver injury. Toxicological Sciences, 115, 307-321.

53. Moore JB. (2010). Non-alcoholic fatty liver disease: the hepatic consequence of obesity and the metabolic syndrome. Proceedings of the Nutrition Society, 69, 211-220

54. Hwang YP, Choi JH, Yun HJ, Han EH, Kim JY, Park BH, Khanal T, Choi JM, Chung YC, Jeong HG. (2011). Anthocyanins from purple sweet potato attenuate dimethylnitrosamine-induced liver injury in rats by inducing Nrf2-mediated antioxidant enzymes and reducing COX-2 and iNOS expression. Food and Chemical Toxicology, 49(1), 93-99.

55. Shin MO, Moon JO. (2010,). Effect of dietary supplementation of grape skin and seeds on liver fibrosis induced by dimethylnitrosamine in rats. Nutrition Research and Practice, 4(5), 369-374.

56. Bast A, Haenen GRM, Doelman CJA. (). Oxidants and Antioxidants. American Journal of Medicine, 1991, 91: 2-13.

57. Luo H. Lv XD. Wang GE. Li YF. Kurihara H.and He RR. (2014). Anti-inflammatory effects of anthocyanins-rich extract from bilberry (Vaccinium Myrtillus L.) on croton oil-induced ear edema and Propionibacterium acnes plus LPS-induced liver damage in mice. Int J Food Sci Nutr. 65(5), 594-601.

58. Talavera S, Felgines C, Texier O, Besson C. Gil-Izquierdo A, Lamaison JL, Remesy C. (2005). Anthocyanin metabolism in rats and their distribution to digestive area, kidney, and brain. Journal of Agricultural and Food Chemistry, 53(10), 3902-3908.

59. Kalt W, Blumberg JB, McDonald JE, Vinqvist-Tymchuk MR, Fillmore SAE, Graf BA, O'Leary JM, Milbury PE. (2008). Identification of anthocyanins in the liver,eye, and brain of blueberry-fed pigs. Journal of agricultural and food chemistry, 56, 705-712.

60. Tang X. Shen T. Jiang X. Xia M. Sun X. Guo H. and Ling W. (2015,). Purified anthocyanins from bilberry and black currant attenuate hepatic mitochondrial dysfunction and steatohepatitis in mice with and choline deficiency. Journal Agricultural and Food Chemistry, 63, 552-561

61. Bao L, Yao XS, Yau CC, Tsi D, Chia CS, Nagai H, Kurihara H. (). Protective Effects of Bilberry (Vaccinium Myrtillus L.) Extract on Restraint Stress-Induced Liver Damage in Mice. Journal of Agricultural and Food Chemistry, 2008, 56(17): 7803-7807

62. Sakakibara H, Ogawa T, Koyanagi A, Kobayashi S, Goda T, Kumazawa S, Kobayashi H, Shimoi K. (). Distribution and excretion of bilberry anthocyanins (corrected) in mice. Journal of Agricultural and Food Chemistry, 2009, 57: 7681-7686.

63. Ichiyanagi T, Shida Y, Rahman MM, Hatano Y, Konishi T. (). Bioavailability and tissue distribution of anthocyanins in bilberry (Vaccinium Myrtillus L.) extract in rats. Journal Agricultural Food Chemistry, 2006, 54 (18): 6578-6587. 